\title{
The evolution of agricultural marketing theory: towards better coordination with general marketing theory
}

\author{
M. T. G. Meulenberg \\ Department of Marketing, Agricultural University, Wageningen, Netherlands
}

Key words: marketing theory, marketing management, agricultural marketing

\begin{abstract}
The thesis of this paper is that in agricultural marketing theory the basic approach to marketing problems should be the 'marketing management' approach. In order to substantiate this thesis, the developments in agricultural marketing and general marketing theory are concisely reviewed. The elaboration of marketing management in agricultural marketing is discussed in relation to the properties of the marketing environment and to the marketing capacities of an agricultural marketing system.
\end{abstract}

\section{Introduction}

'Marketing management', i.e. decision-making with respect to the marketing mix (product, price, promotion and distribution), on the basis of customer orientation has become the basic approach to marketing of goods and services. This is not the case in the agricultural marketing discipline. In fact, since the 1950s (Kotler, 1967; McCarthy, 1964; Kohls, 1955), general marketing and agricultural marketing theory seem different branches of marketing. This divergence is not fruitful for agricultural marketing.

Some scholars in agricultural marketing have been aware of this gap between agricultural marketing and general marketing theory. For instance, Polopolus stated in his presidential address to the American Association of Agricultural Economists: 'There are more arguments that marketing agricultural products is not an isolated operation but an integrated operation' (Polopolus, 1982). Also, various agricultural economists have partially incorporated the marketing management approach in agricultural marketing theory (e.g. Breymeier, 1976; Bateman, 1976; Shaffer, 1983; Padberg \& Westgren, 1983; Purcell, 1979; Yon, 1976; Besch, 1981).

In this contribution it is claimed that also in agricultural marketing theory the basic approach to marketing problems should be 'marketing management'.

The paper is organized as follows. First, the evolution of general marketing and agricultural marketing is discussed briefly. The discussion is confined to the main similarities and differences of both disciplines. Within a systems framework the marketing management approach to agricultural marketing is elaborated. It is ar- 
gued that better coordination between general marketing and agricultural marketing as a discipline is advantageous to agricultural marketing theory. Finally some conclusions are drawn.

\section{The evolution of general marketing and agricultural marketing theory}

Period 1910-1950: the beginning of marketing thought, agricultural marketing and general marketing theory are similar

According to Bartels, 'The beginnings of marketing thought might be dated at the beginning of the twentieth century, for it was between 1900 and 1910 that "marketing" was conceived or discovered and initial expression was given to ideas which became incorporated in the body of marketing thought', and, according to the same author, 'Marketing was a discovery only as "marketing" is recognized as an idea and not simply as an activity. Until the idea was conceived to which the term "marketing" was applied the simple activity had been called only "trade", "distribution" or "exchange"" (Bartels, 1970). The basic theme of marketing in the 1920s were the activities involved in the transfer of goods and in the exchange of title (Bartels, 1970). Soon three classic approaches to marketing problems developed: the functional, institutional and commodity approach. These approaches were also taken by agricultural marketing. In fact in the beginning of marketing as a discipline agricultural marketers contributed to general marketing theory. Amongst others, Weld, an agricultural marketer, contributed to the functional approach (Weld, 1920). While from 1920 to 1950 research and conceptual thinking about marketing expanded substantially, in the United States in particular, the functional, institutional and commodity approach in marketing prevailed yet (e.g. Bartels, 1970). The resemblance between agricultural marketing and general marketing until about 1950 may be brought about by (a) the centrality of distribution problems in marketing and (b) the predominantly economic approach towards marketing problems: 'Where the pre-1940 period was preoccupied with trying to make the same product cheaper the postwar period saw a new dimension added to the competition in which the focus was to try and make the old product better, or even more bold, to try and launch a new product' (McKitterick, 1957).

The congruence between general marketing theory and agricultural marketing as a discipline appears also from early definitions of marketing: 'Those business activities involved in the flow of goods and services from production to consumption' (National Association of Marketing Teachers, Autumn 1935) and 'those efforts which effect transfers in the ownership of goods and services and care for their physical distribution' (Clark \& Clark, 1947), or 'Marketing is the economic process by means of which goods and services are exchanged and their values determined in terms of money prices' (Duddy \& Revzan, 1953). These definitions compare well with definitions of agricultural marketing in the 1970s: 'Marketing is the performance of all business activities involved in the flow of goods and services from the point of initial agricultural production until they are in the hands of the ultimate consumer' (Kohls \& Downey, 1972). Also in Europe where, at least in the non-Anglophone countries, the term 'marketing' was not used until 1950, and study of the 
commercial process concentrated on marketing functions such as collection/assembling, sorting, storage and transport. In Germany and the Netherlands economic study of these marketing functions was investigated in the analysis of 'Handel' (e.g. Schär, 1921, being quoted in Muiswinkel, 1962). Redlich developed a system of functions performed by the trader, similar to the marketing functions (Redlich, 1932).

Period since 1950, rapid expansion of marketing theory: marketing management, consumer orientation, multidisciplinary approach

After the second world war markets for many consumer goods changed from 'sellers' markets to 'buyers' markets, amongst other things because of increasing disposable income of consumers, because of increasing production capacity of industries and because of expanding international trade. In conjunction with this change of markets the main change in general marketing was the shift towards marketing management: decision-making with respect to the marketing mix (product, price, promotion, distribution) on the basis of consumer orientation. Marketing became multidisciplinary, in some instances even interdisciplinary: increasingly concepts and research methods were used from behavioural sciences, decision sciences and systems theory. Marketing changed from the consensus 'marketing is essentially an economic activity' and 'the initiator of marketing activities and programmes is the marketer and not the consumer' towards 'marketing is essentially "the exchange of values" ' and 'the consumer is more powerful than the marketer', consequently 'behavioural perspectives in place of economic perspectives' are more important 'to develop a realistic marketing theory' (Sheth \& Gardner, 1982). General marketing theory centred on marketing management, that is defined as '. . the analysis, planning, implementation, and control of programmes designed to create, build, and maintain beneficial exchanges and relationships with target markets for the purpose of achieving organizational objectives' (Kotler, 1984).

Of course, the importance of consumers and of managerial decision-making was recognized also in the 1930 s but did not play such a central role in marketing theory yet. '. . the trade structure was regarded as an impenetrable barrier - it was the market, and this fellow we have been calling the end user was the exclusive problem of the dealer, and no concern of the manufacturer' (McKitterick, 1957).

Since the firm establishment of the marketing management approach various new developments emerged in marketing discipline, which are essentially based on marketing management. Some important developments are:

- specialization of marketing management to its use in specific organizations, companies, institutions and markets, such as non-profit marketing, retail marketing, industrial marketing (the marketing of raw materials, capital goods and other production means to producers), marketing of services and export marketing.

- a specific theoretical view towards marketing. Carman (1980) distinguishes six paradigms of marketing: 'the microeconomic paradigm which looks at an abstraction of a market, usually pure competition in a one level structure; the persuasion/attitude change paradigm focusing on one aspect of the process of marketing - the information and persuasion required by one actor to achieve a desired be- 


\section{T. G. MEULENBERG}

havior from another; the conflict resolution paradigm whose theories largely have been captured by other paradigms; the general system paradigm, focusing on the interrelationships between institutions in a system; the functionalist paradigm, concerned with decision-making regarding the functions performed by institutions within society; and the social exchange paradigm focusing on the phenomenon of exchange between social actors or institutions regardless of the functions being performed or the institutions involved'.

- marketing at the level of business units: strategic marketing; marketing at sector level, sector marketing; and marketing from a societal perspective, macro-marketing. These extensions have broadened the marketing discipline as appears from recent definitions, such as '. . . those activities that relate an organization successfully to its environment' (Hughes, 1978) or 'Marketing is a social process by which individuals and groups obtain what they need and want through creating and exchanging products and value with others' (Kotler, 1984). However, there seems to be consensus about what general marketing theory is concerned with. Hunt (1983) summarizes this as follows: 'The behaviors of buyers directed at consummating exchanges; the behaviors of sellers directed at consummating exchanges; the institutional framework directed at consummating/facilitating exchanges; the consequences on society of the behaviors of buyers, the behaviors of sellers and the institutional framework directed at consummating and/or facilitating exchanges.'

\section{Evolution of agricultural marketing as a discipline since 1950}

Since the 1950s agricultural marketing has not kept track with general marketing discipline: the marketing management approach did not get foothold in agricultural marketing. Possibly the following reasons have brought about this different evolution:

- individual farmers have scarce contacts with the final consumer, and have limited capacities for managing the marketing mix (price, product, promotion and distribution);

- agricultural marketing is operating often within institutional and technical constraints, like those of government policies;

- the strong adherence of agricultural marketing to economic theory as its scientific foundation, also after 1950 , interferes with a multidisciplinary approach to agricultural marketing.

These arguments, however, do not justify that agricultural marketing discipline should refrain from marketing management. We will substantiate this point in the next section. But first it seems appropriate to review some important developments in agricultural marketing. It is out of the scope of this article to review completely the vast amount of research in this field.

While agricultural marketing had absorbed to a limited extent only developments in general marketing theory since the 1950s, it has expanded substantially in its familiar field, for example: market structure analysis (Marion \& Mueller, 1983; Connor et al., 1985), marketing efficiency studies (French, 1977), regional and spatial analysis (Takayama \& Judge, 1971), economic demand analysis and price analysis (Fox, 1953; McFarquhar, 1971; Tomek, 1983; Wöhlken, 1979) and 
marketing institutions like future markets, marketing cooperatives and marketing boards (Hoos, 1979; Working, 1953; Gray, 1963). Bain's 'Industrial organizaton' (1968) has been a theoretical basis for analysing organization and competition in agricultural markets.

Some elements of change in general marketing theory have been picked up by scholars of agricultural marketing. Breymeier wrote: 'Although agricultural marketing has not been transformed that much, the industrial marketing image helps to refute the older agrarian notion that regards production of farm products as a primary, autonomous farm based activity and marketing as a secondary, subservient, and non farm' (Breymeier, 1976). By stressing specialization, the sequential character of the marketing process and the composite character of sequential activities, Breymeier also implicitly advocates, in our opinion, the systems approach to the marketing of agricultural products through the marketing channel. But the title of his book 'The economics of product markets of agriculture' indicates Breymeier's essentially economic approach. Bateman (1976) discussed the behavioural analysis of food marketing at length. Kohls \& Downey (1972) underline the importance of the consumer as ". . the overall ruler and coordinator of marketing activities ... ', but do not deal with agricultural marketing as decision-making oriented at satisfaction of consumers' wants and needs. The same holds for the most recent edition of this leading textbook (Kohls \& Uhl, 1985). Purcell (1979) stresses a systems approach to agricultural marketing: ‘. . . emphasis is placed on the workings of the marketing system as the means of achieving coordination between production and consumer demands', but he concentrates mainly on the pricing system. Schaffer (1983) has propagated the need for the identification of consumers' preferences and the articulation of these preferences in agricultural marketing, and Padberg \& Westgren (1983) underline the societal consequences of product policy.

Other scholars of agricultural marketing take the marketing management approach but apply it especially on marketing by agribusiness companies (Besch, 1981; Yon, 1976; Branson \& Norvell, 1983). Farris (1983) mentions amongst others the following subjects, being important for future agricultural marketing: problem areas related to regulation, environmental quality, food safety, quality, nutrition and various types of subsidized food consumption and efficiency of marketing.

It is our thesis that a fundamental analysis of agricultural marketing problems today calls for a marketing management approach. Arguments for this thesis are as follows.

- Consumer demand with respect to food in Western countries is, in terms of energy intake, satiated. Population growth in Western Countries is stagnating. Consequently, stimulating demand for a food product, often at the cost of another, requires an integrated programme of the 'marketing mix' from the point of view of consumers' wants and needs.

- Marketing channels for agricultural products evolve towards vertical marketing systems.

- The strong bargaining power of retail chains in the marketing channel forces food industry and wholesalers to integrated marketing operations. 
- Decreasing capacities and willingness of governments to support agriculture financially stimulate an agricultural marketing from the consumers' point of view.

\section{Marketing management approach to agricultural marketing problems}

It has been argued that also in agricultural marketing theory there is a need for marketing management: organizing the marketing mix (product, price, promotion, distribution) in a consistent policy based on consumers' orientation. The usefulness of this approach will be discussed within the framework of the system's concepts: objectives, environment, instruments and organizational structure, subsystems. It will also be illustrated how agricultural marketing as a discipline can profit from the achievements of general marketing theory by using the management approach. It is demonstrated how the traditional functional approach in agricultural marketing can be looked upon as a special case of marketing management.

\section{Objectives of the marketing system}

In general marketing theory the main distinction in objectives is 'profit' versus 'nonprofit'. Within profit orientation alternatives are: maximization of profit or of market share, a specific return on investment, or a satisficing objective. Traditionally farmers are profit-oriented. However, farmers' responsibilities in maintaining landscape may add non-profit-oriented objectives which are sponsored by the government. In the latter case agriculture marketing might learn a great deal from 'non-profit' marketing theory (e.g. Kotler, 1975). Maintenance or expansion of market share will become more important in agricultural marketing, because of severe competition in various West European and international markets. Agricultural marketing can profit from market share analysis in general marketing (Lilien \& Kotler, 1983; Naert \& Leeflang, 1978). Models combining market demand for the generic product with market share of specific varieties are useful in this respect (Neslin \& Shoemaker, 1983).

Differences in marketing objectives might become more important in the future because of a segmentation between profit-maximizing specialized farmers and satisficing part-time farmers, and organic food farmers.

\section{Environment}

The task environment of a marketing system consists of consumers, competitors, distributive companies, and government. Marketing management basically is consumer-oriented, in a broader sense environment-oriented. Consumers, competitors and distribution companies are the object of marketing policy. Government and consumer organizations put side conditions to marketing operations. When the environment does not change, in other words when it is static, a marketing system will get in equilibrium with its environment and marketing management ends up in a routine operation. In that case there will be less need for continuous analysis, planning and control, the basic activities of marketing management. A static envi- 
ronment as defined is essentially a theoretic concept, but markets can approach more or less that situation. Agricultural markets in traditional societies resemble a static environment more than Western agricultural markets. The latter are dynamic because of changing consumers, competitors, distributive companies and government policies. It is out of the scope of this article to review all changes in West European agricultural markets. We will confine ourselves to some major changes.

Consumers change in many respects. Important are demographic changes, such as decreasing rate of population growth, changing structure of families, and, at least in some Western countries like the Netherlands, a growing importance of ethnic groups. Consumers dispose of a substantial discretionary income and have more freedom to spend their purchasing power in accordance with their needs and wants.

Life style (activities, opinions and interests) is changing because of more leisure, travelling, outdoor working housewives, concern about health, and environmental problems. Education and more information accelerate this change. Consequently, the analysis of consumer behaviour, also in agricultural marketing, will have to become multidisciplinary/interdisciplinary. 'No other area in marketing has had a greater dominance for such a long time period as buyer behavior. While it seems to have peaked in recent years, it is still the most dominant area of research and theory in marketing' (Sheth \& Gardner, 1982; see also: Engel \& Blackwell, 1982; Schiffman \& Kanuk, 1986). Integral models of consumer behaviour, such as those of Engel, Kollat and Blackwell (Engel \& Blackwell, 1982); Howard \& Sheth (1969) and Bettman (1979), seem relevant to consumer demand for food and agricultural products. They have been applied, for example, to the demand for liquid milk (Termorshuizen, 1982; Termorshuizen et al., 1986). The analysis of specific aspects of consumer behaviour is increasing. Perception of food products (Wierenga, 1980; Werner, 1982; Deters, 1985) has been analyzed extensively in order to develop product maps describing the position of various products/brands on important product dimensions, say taste and nutritional value. Attention has been paid to quality perception of food and agricultural products by consumers (Steenkamp et al., 1985; Steenkamp \& Meulenberg, 1986). Attitude research is well known in agricultural marketing. Preference analysis by conjoint analysis (Green \& Srinivasan, 1978) has become familiar to the analysis of food consumption. Stochastic consumer models such as Markov processes and linear learning models have been applied to brand choice for agricultural products (e.g. Wierenga, 1974; van Tilburg, 1984).

While behavioural analyses of consumers have been applied in agricultural marketing problems, they are not integrated in agricultural marketing theory yet. Padberg \& Westgren (1983) and Shaffer (1983) recently have, in our opinion, argued for more integration too.

Competition is increasing in agricultural markets. Reasons for this increase are well known: in many markets, such as the milk and dairy markets, there is an oversupply; similarity of food and agricultural products supplied to the market makes it difficult for a company to develop a niche in the market, a specific market segment; international trade in food and agricultural products is increasing because of less tra- 
de barriers - at least within the EC - and because of internationally operating food and trading companies; vertical competition increases because of the bargaining power of retail companies.

Agricultural marketing as a discipline has not paid much attention to competitive strategies. It might profit from the work on that subject in general marketing theory (Porter, 1980).

Distribution traditionally has received much attention in agricultural marketing: transport, storage and processing. The strategic position of retail companies makes the choice of channels and the marketing programme vis à vis the retailer also important.

A broad view on distribution has emerged in general marketing theory: distribution strategy (choice of a channel); distribution location (number of outlets); distribution logistics (planning of physical functions) and distribution management (fitting marketing programmes to the requirements of retail companies). This broad view seems useful to agricultural marketing too.

Governmental policies relevant to agricultural marketing originate from both economic and societal responsibilities. These responsibilities increase because of surpluses in international markets, of concern about healthiness of food and of concern about environment. Within general marketing theory macromarketing analyses societal aspects of marketing (e.g. Fisk, 1981). The concepts of macromarketing seem useful to the agricultural marketing discipline in its relationship to environment, and to the government in particular.

\section{Instruments of the marketing system}

In agricultural marketing theory marketing processes are investigated by analysing market structure and marketing functions: exchange, physical and facilitating functions. Marketing management takes a more fundamental approach to marketing processes, namely the performance of a marketing policy by the marketing mix: product (what to supply?), price (at what cost?), promotion (what information?), distribution (where, when, what service?). ${ }^{1}$

It is our thesis that in principle this approach should be taken in agricultural marketing as well. Dynamics of the marketing environment call for such procedure. Also technological progress augmenting the greater potential of companies, because of research and development, call for marketing management. The extent in which a marketer can manage the marketing mix differs, however, substantially. Individual farmers have limited capacities in this respect: they are price takers, have no brands, have no promotional programmes and cannot set up marketing channels for their products. Small trading and processing companies in agribusiness have also limited capacities in this respect. We suggest that company size and prod-

\footnotetext{
${ }^{1}$ Some authors list additional instruments, such as public relations (promotion at the company level), service (an element of product or distribution) and politics (related to promotion and price).
} 
uct differentiation determine the capacity of a marketer to manage the marketing mix. Table 1 provides a schematic picture of marketing capacities in relation to company size and product differentiation. The following alternatives are distinguished.

Case 1. The 'limited-marketing' firm. Small firms supplying homogeneous products have limited marketing capacities. A family farm, selling products in a market of

Table 1. Influence of company size and product differentiation on the marketing capacity of a marketing system (for explanation see text).

\begin{tabular}{lll}
\hline Company size & Product differentiation & \\
\cline { 2 - 3 } & small & large \\
Small & $\begin{array}{l}\text { 'Limited-marketing firm' } \\
\text { (Case 1) }\end{array}$ & $\begin{array}{l}\text { 'Specialist in a market niche' } \\
\text { (Case 2) }\end{array}$ \\
Large & $\begin{array}{l}\text { 'Price and distribution oriented marketer' } \\
\text { (Case 3) }\end{array}$ & $\begin{array}{l}\text { 'The complete marketer } \\
\text { (Case 4) }\end{array}$ \\
\hline
\end{tabular}

Table 2. Reduction of marketing mix towards marketing functions as a consequence of marketing capacities of a marketer.

\begin{tabular}{|c|c|c|}
\hline Marketing mix & $\begin{array}{l}\text { Oligopoly with product differentiation } \\
\text { e.g. large food company }\end{array}$ & $\begin{array}{l}\text { Pure competition } \\
\text { e.g. family farm }\end{array}$ \\
\hline Product & $\begin{array}{l}\text { Product mix } \\
\text { Attributes } \\
\text { Assortment } \\
\text { Brand } \\
\text { Package } \\
\text { Image } \\
\text { Quality }\end{array}$ & $\begin{array}{l}\text { Facilitating functions } \\
\text { Grading, sorting }\end{array}$ \\
\hline Price & $\begin{array}{l}\text { Price mix } \\
\text { General price level } \\
\text { Price discrimination } \\
\text { Discounts } \\
\text { Psychological pricing }\end{array}$ & $\begin{array}{l}\text { Exchange functions } \\
\text { Buying/selling }\end{array}$ \\
\hline Promotion & $\begin{array}{l}\text { Promotion mix } \\
\text { Advertising } \\
\text { 'Below the line' }\end{array}$ & $\begin{array}{l}\text { Facilitating functions } \\
\text { Information }\end{array}$ \\
\hline Distribution & $\begin{array}{l}\text { Distribution mix } \\
\text { Distribution strategy } \\
\\
\text { Distribution location } \\
\text { Distribution logistics } \\
\text { Distribution management }\end{array}$ & $\begin{array}{l}\text { Exchange functions } \\
\text { Channel decision } \\
\text { Physical functions } \\
\text { Transport, storage } \\
\text { Facilitating functions } \\
\text { Credit }\end{array}$ \\
\hline
\end{tabular}


pure competition, is an example. Of course, within the constraints of its capacities a firm will try to realize the best marketing result: marketing management reduces to optimal execution of marketing functions as indicated in Table 2.

Case 2. 'The specialist in a market niche'. Small companies supplying differentiated products and services to a particular market segment: monopolistic competition. Specialty shops and specialized small industries are examples. This type of firm is not numerous in agriculture. Farmers producing cheese or butter at the farm and selling to a special clientele seem an example.

Case 3. 'The price and distribution oriented marketer'. Large companies selling homogeneous products by definition cannot compete through product differentiation. They will search for competitive advantage by effective and efficient distribution (better service, lower costs) or by competitive prices (by lower costs). In some markets price competition may lead to price wars. Therefore companies will try to protect themselves against catastrophic price competition by formal and informal pricing agreements or by product differentiation. The latter actually implies a shift towards case 4 of Table 1 .

Case 4. 'The complete marketer'. Large companies supplying differentiated products to the market dispose, in principle, of a broad range of marketing instruments. The market structure of oligopoly with product differentiation is characteristic for this type of company.

It has been argued that dynamic agricultural markets of today call for extensive use of the marketing mix: not only distribution and price but also product (assortment and quality) and promotion have become important. Since cases 1 and 3 of Table 1 do not fit well to these requirements there is a shift in agricultural markets to case 4 and, to a lesser extent, to case 2 . In this way the need for marketing management is changing market structure. Companies and organizational structures have emerged, by amalgamation, by forward and backward integration, which can manage the marketing mix adequately (case 4 of Table 1). Examples are big dairy cooperatives, which have come into existence in many West European countries. Some farmers produce and market special products for particular consumer groups, such as cheese made at the farm (case 2).

It is appropriate now to elaborate our point that agricultural marketing can profit better from developments in general marketing theory by taking the marketing management approach. Theories about the relationship between marketing instruments and sales or market share are numerous. They are helpful to set up adequate agricultural marketing programmes too. Some examples will illustrate the point (see for more information e.g. Lilien \& Kotler, 1983).

Product policies. A great many theories/concepts about product as a marketing instrument have been set forth.

Product life cycle theory is concerned with market penetration of new products from introductory stage until obsolence (Wind, 1982). Dynamics of agriculture markets make the product life cycle more relevant for agricultural marketing. The rapid change in assortment of flowers in the Netherlands seems an example.

Market segmentation - fitting products to the needs and wants of specific target 
groups being relatively homogeneous in wants and needs and having sufficient size - is a useful concept in agricultural marketing too. Also many agricultural producers are supplying special target groups, for example with respect to quality or price consciousness. Therefore, general methods to establish market segments are useful in agricultural marketing (Frank et al., 1972; van Tilburg, 1984).

Product portfolio models have been developed, which evaluate strengths and weaknesses of product assortment on the basis of criteria like market share and market growth by the Boston Consulting Group, or business strengths and industry attractiveness by McKinsey (see for instance Wind, 1982). Such models are, at least conceptually, useful for strategic marketing by agribusiness companies. They offer also a frame of reference for analysing the product portfolio of a specific sector of agriculture, say Dutch fresh vegetable industry.

Price policies. Price formation has always been a main theme of the agricultural marketing discipline (e.g. Tomek \& Robinson, 1972; Tomek, 1983; Purcell, 1979). Investigations concern in particular price formation of the generic product, the formation of marketing margins, and price formation institutions such as futures markets and auctions.

General marketing theory is focussed both on price decision-making and price formation. Also attention has been paid to behavioural aspects of pricing, for instance price as an indicator of quality (e.g. Gabor \& Granger, 1966; Monroe, 1979). Price decision-making under uncertainty is another subject, which has been dealt with in bidding models and competitive pricing models (e.g. Monroe, 1979). Recently models have been proposed for pricing throughout the life cycle (e.g. Lilien \& Kotler, 1983).

Since agricultural and food producers increasingly compete for consumer acceptance with other suppliers pricing has to be based both on economic and behavioural concepts.

Promotion. In marketing management many promotional models have been developed. Econometric models measure the influence of promotional expenditure on sales, or market share. Also in agricultural marketing econometric models have been applied extensively to measure the effect of promotional expenditure for generic products such as oranges (Nerlove \& Waugh, 1961). Models have been constructed which measure the communicative impact of advertising and the combined influence of advertising together with other marketing instruments on sales, for instance Brandaid (Little, 1975).

Also in agricultural marketing there is a need for integration of promotion in the total marketing mix. The need for planning promotional expenditure over the various types of promotion, such as advertising and below-the-line promotions, exhibitions and public relations, calls also in agricultural marketing for both an economic and behavioural approach to promotion. In this respect agricultural marketing as a discipline can profit from findings in general marketing theory.

Distribution policies. Physical distribution has been analyzed at length in agricultural marketing, in particular transport and storage. In general marketing theory distribution policy has been elaborated in distribution strategy, distribution location, distribution logistics and distribution management (Lilien \& Kotler, 1983). Models 
have been developed to explain the development of marketing channels, for example models which assume minimization of the number of transactions or the minimization of total costs in the marketing channel as the objective (e.g. Stern \& Ansary, 1982; Mallen, 1977). Bucklin (1965) introduced the concepts postponement and speculation to determine the structure of a marketing channel. Decision procedures have been proposed in general marketing theory to choose a marketing channel. Also concepts and models have been developed which may be helpful in determining the appropriate number of outlets, such as intensive, selective, and exclusive distribution. Physical distribution has been extended towards integrated planning of 'physical functions' such as transport and storage. It is, on its turn, integrated with other logistical functions, such as materials handling, into the discipline of 'business logistics' (e.g. Bowersox, 1978).

Distribution management, as a concept, stresses the necessity for fitting marketing programmes to the needs of wholesalers and retailers. Important in this respect is also the behavioural analysis of marketing channels, for instance the analysis of power in the marketing channel (e.g. Stern \& Ansary, 1982). This broad approach to distribution as a marketing instrument seems increasingly relevant to marketing of agricultural products and food.

\section{Organization of marketing systems and subsystems}

In marketing theory many concepts and models have been developed about the organization of marketing management, product management, and sales force (Lodish, 1971). These concepts and models have been applied by large agribusiness companies extensively. In agricultural marketing there is also a need for the organization of marketing operations through the various subsystems of the marketing channel. Theories about marketing channel structure in general marketing theory seem relevant in this respect to agricultural marketing theory (Stern \& Ansary, 1982).

Another organizational issue of agricultural marketing is that institutions as cooperatives, auctions or commodity boards have to adapt their organization to perform an adequate marketing management policy (Meulenberg, 1984).

It is also important to strike a good balance between marketing activities of individual agribusiness companies and marketing activities for the generic product by sector institutions as marketing boards and marketing orders. Changing marketing capacities of individual agribusiness companies require a permanent assessment of the coordination of marketing activities between individual companies and sectoral marketing institutions.

\section{Conclusion}

It has been argued that agricultural marketing, as a scientific discipline, should be based on the marketing management approach as it is practised in general marketing theory.

If the marketing management approach will not be pursued consistently, the ag- 
ricultural marketing discipline ultimately will split into agribusiness marketing and agricultural marketing, the latter covering some specific marketing items at the farm level only.

In some marketing situations marketing management will reduce to the performance of specific marketing functions only, because of the characteristics of the marketing environment and/or of limited marketing capacities of a marketer.

By taking a marketing management approach, agricultural marketing can profit most from the findings of general marketing theory.

\section{References}

Bain, J. S., 1968. Industrial organization. John Wiley, New York.

Bartels, R., 1970. Marketing theory and metatheory. R. D. Irwin, Homewood, Ill.

Bateman, D. J., 1976. Agricultural marketing: a review of the literature of marketing theory and of selected applications. Journal of Agricultural Economics 27: 171-224.

Besch, M., 1981. Agrar-Marketing. Marketing Zeitschrift für Forschung und Praxis 3(1): 27-36.

Bettman, J. R., 1979. An information processing approach theory of consumer choice. Addison Wesley, Reading, Mass.

Breymeier, H. F., 1976. Economics of the product markets of agriculture. Iowa State University Press, Ames, Iowa.

Bowersox, D. J., 1978. Logistical management. Macmillan, New York.

Branson, R. E. \& D. G. Norvell, 1983. Introduction to agricultural marketing. McGraw-Hill, New York.

Bucklin, L. P., 1965. Postponement, speculation and the structure of distribution channels. Journal of Marketing Research 2(1): 26-31.

Carman, J. M., 1980. Paradigms for marketing theory. Research in Marketing 3: 1-36.

Clark, F. E. \& C. P. Clark, 1947. Principles of marketing, 3rd ed. Macmillan, New York.

Connor, J. M., R. T. Rogers, B. W. Marion \& W. F. Mueller, 1985. The food manufacturing industries, Lexington Books. D. C. Heath, Lexington, Mass.

Deters, S., 1985. Analyse der Verbraucher- und Händlerpräferenzen bei Frischgemüse. Forschungsberichte zur Ökonomie im Gartenbau No 55, Hannover und Weihenstephan.

Duddy, E. A. \& D. A. Revzan, 1953. Marketing. An institutional approach, 2nd ed. McGraw-Hill, New York.

Engel, J. F. \& R. D. Blackwell, 1982. Consumer behavior, 4th ed. The Dryden Press, Chicago.

Farris, P. L., 1983. Agricultural marketing research in perspective. In: P. L. Farris (Ed.), Future frontiers in agricultural marketing research. Iowa State University Press, Ames, Iowa.

Fisk, G., 1981. Macromarketing: A state of the art review. Working Paper Series 81-1, Management Center, School of Management, Syracuse University, Syracuse, New York.

Fox, K. A., 1953. The analysis of demand for farm products. USDA Technical Bulletin 1081. USDA, Washington, D.C..

Frank, R. E., W. F. Massy \& Y. Wind, 1972. Market segmentation. Prentice Hall, Englewood Cliffs, N.J.

French, B. C., 1977. The analysis of productive efficiency in agricultural marketing, models, methods and progress. In: L. R. Martin (Ed.), A survey of agricultural economics literature, Vol. 1: 93-206. University of Minnesota Press, Minneapolis.

Gabor, A. \& C. W. J. Granger, 1966. Price as an indicator of quality: Report on an inquiry. Economica 46: $43-70$.

Gray, R. W., 1963. Onions revisited. Journal of Farm Economics 45.

Green, P. E. \& V. Srinivasan, 1978. Conjoint analysis in consumer research: Issues and outlook. Journal of Consumer Research 5 (September): 103-123.

Howard, J. A. \& J. N. Sheth, 1969. The theory of buyer behavior. John Wiley, New York. 
Hoos, S. (Ed.), 1979. Agricultural marketing boards - An institutional perspective. Ballinger, Cambridge, Mass.

Hughes, G. D., 1978. Marketing management: A planning approach. Addison-Wesley, Reading, Mass.

Hunt, S. D., 1983. General theories and the fundamental explananda of marketing. Journal of Marketing 47: 9-17.

Kohls, R. L., 1955. Marketing of agricultural products. Macmillan, New York.

Kohls, R. L. \& W. D. Downey, 1972. Marketing of agricultural products, 4th ed. Macmillan, New York.

Kohls, R. L. \& J. N. Uh1, 1985. Marketing of agricultural products, 6th ed. Macmillan, New York.

Kotler, P., 1967. Marketing management: Analysis planning and control. Prentice-Hall, Englewood Cliffs, N.J.

Kotler, P., 1975. Marketing for non-profit organizations. Prentice-Hall, Englewood Cliffs, N.J.

Kotler, P., 1984. Marketing management: Analysis planning and control, 5th ed. Prentice-Hall, Englewood Cliffs, N.J.

Lilien, G. L. \& P. Kotler, 1983. Marketing decision making, a model-building approach. Harper and Row, New York.

Little, J. D. C., 1975. Brandaid: A marketing mix model, Part 1: Structure; Part 2: Implementation, calibration and case study. Operations Research 23(4) 628-673.

Lodish, L. M., 1971. Callplan: An interactive salesman's call planning system. Management Science 18(4), Part II: $25-40$.

Mallen, B. E., 1977. Principles of marketing channel management. Lexington, Lexington, Mass.

Marion, B. W. \& W. F. Mueller, 1983. Industrial organization, economic power, and the food system. In: P. L. Farris (Ed.), Future frontiers in marketing research, p. 16-38. Iowa State University Press, Ames, Iowa.

McCarthy, E. J., 1964. Basic marketing: A managerial approach, rev. ed. R. D. Irwin, Homewood, Ill.

McFarquhar, A. M. M. (Ed.), 1971. Europe's future food and agriculture. North-Holland Publishing Company, Amsterdam.

McKitterick, J. B., 1957. What is the marketing management concept? In: F. M. Bass (Ed.), The frontiers of marketing thought and science. American Marketing Association, Chicago.

Meulenberg, M. T. G., 1984. Marketing management by agricultural marketing institutions: A case study of horticultural auctions in the Netherlands. IVth European Congress of Agricultural Economists, Working Group B2 Papers (Kiel, 1984).

Monroe, K., 1979. Pricing making profitable decisions. McGraw-Hill, New York.

Muiswinkel, F. L., 1962. Handel, markt en beurs, 3e druk. Noord Hollandsche Uitgeversmaatschappij, Amsterdam.

Naert, P. A. \& P. S. H. Leeflang, 1978. Building implementable marketing models. Martinus Nijhoff, Leiden.

Nerlove, M. \& F. V. Waugh, 1961. Advertising without supply control: Some implications of a study of the advertising of oranges. Journal of Farm Economics 43(4): 813-837.

Neslin, S. A. \& R. W. Shoemaker, 1983. Using a natural experiment to estimate price elasticity: The 1974 sugar shortage and the ready to eat cereal market. Journal of Marketing 47 (winter): 44-57.

Padberg, D. J. \& R. E. Westgren, 1983. Adaptability of consumers and manufacturers to changes in cultural patterns and socioeconomic values. In: P. L. Farris (Ed.), Future frontiers in agricultural marketing research. Iowa State University Press, Ames, Iowa.

Polopolus, L., 1982. Agricultural economics beyond the farm gate. American Journal of Agricultural Economics 64(5): 803-810.

Porter, M., 1980. Competitive strategy: Techniques for analyzing industries and competitors. Macmillan, New York.

Purcell, W., 1979. Agricultural marketing: Systems coordination, cash and futures prices. Reston Inc., Reston, Virginia.

Redlich, F., 1932. System der Handelsfunktionen. Schmollers Jahrbuch 56: 27-50.

Schiffman, L. G. \& L. L. Kanuk, 1986. Consumer behavior, 2nd ed. Prentice-Hall, Englewood Cliffs, N.J.

Shaffer, J. D., 1983. Preference articulation and food system performance. In: J. P. Farris (Ed.), Future 
frontiers in agricultural marketing research. Iowa State University Press, Ames, Iowa.

Sheth, J. N. \& D. M. Gardner, 1982. History of marketing thought: An update. In: R. F. Bush \& S. D. Hunt (Eds.), Marketing theory: Philosophy of science perspectives. A.M.A. Proceedings Series, Chicago, Ill.

Steenkamp, J. B. E. M., B. Wierenga \& M. T. G. Meulenberg, 1985. Quality perception of food products. Proceedings of the 14th Annual Conference of the European Marketing Academy (Bielefeld): 346-366.

Steenkamp, J. B. E. M. \& M. T. G. Meulenberg, 1986. Perceived quality and its relationship to preference: An application to margarine and butter. Proceedings of the 15th Annual Conference of the European Marketing Academy (Helsinki).

Stern, W. \& A. I. El Ansary, 1982. Marketing channels, 2nd ed. Prentice-Hall, Englewood Cliffs, N.J.

Takayama, T. \& G. G. Judge, 1971. Spatial and temporal price and allocation models. North-Holland Publishing Company, Amsterdam.

Termorshuizen, J. G., 1982. Het consumentengedrag met betrekking tot melk. Thesis, Wageningen.

Termorshuizen, J. G., M. T. G. Meulenberg \& B. Wierenga, 1986. Consumer behaviour in respect of milk in the Netherlands. European Review of Agricultural Economics 31(1): 1-21.

Tilburg, A. van, 1984. Consumer choice of cut flowers and pot plants. Agricultural University Wageningen Papers 84-2, Wageningen.

Tomek, W. G., 1983. Alternative pricing mechanisms in agriculture. In: P. L. Farris (Ed.), Future frontiers in agricultural marketing research. Iowa State University Press, Ames, Iowa.

Tomek, W. G. \& K. L. Robinson, 1972. Agricultural product prices. Cornell University Press, Ithaca.

Weld, L. D. H., 1920. The marketing of farm products. Macmillan, New York.

Werner, J., 1982. Psychologische Marktsegmentierung beim Absatz von Äpfeln. Forschungsberichte zur Ökonomie im Gartenbau 38, Hannover und Weihenstephan.

Wierenga, B., 1974. An investigation of brand choice processes. Universitaire Pers Rotterdam, Rotterdam.

Wierenga, B., 1980. Multidimensional models for the analysis of consumers' perception and preferences with respect to agricultural and food products. Journal of Agricultural Economics 31(1): 83-97.

Wind, Y. J., 1982. Product policy: Concepts, methods and strategy. Addison-Wesley, Reading, Mass.

Wöhlken, E., 1979. Einführung in die landwirtschaftliche Marktlehre. Eugen Ulmer, Stuttgart.

Working, H., 1953. Hedging reconsidered. Journal of Farm Economics 35: 544-561.

Yon, B., 1976. Marketing agro-alimentaire. Dalloz, Paris. 